\title{
Yerel Basında Kadın Çalışanların Konumu ve Sorunları: Giresun Yerel Basın Örneği
}

Öz

\author{
Nedim Serhat BİLECEN*
}

Toplumsal cinsiyet ve cinsiyet ayrımcılı̆̆ kavramları, bireylerin içinde bulundukları toplumun kültürel ve sosyo-ekonomik yapısında farklı kadınlık ve erkeklik rollerinin yüklendiği tartışma alanlarıdır. Özellikle ataerkil toplumlarda kadınların yaşam ve çalışma alanı kamusal alandan soyutlanarak ev ile sınırlıdır. Bu tür toplumsal yapılarda erkek egemenliği toplumun her katmanında kendini gösterir. Aile yaşamından, eğitim hayatına, sosyal yaşamdan iş hayatına kadar birçok farklı alanda cinsiyet ayrımcılı̆̆ 1 kendini hissettirmektedir. Medya sektörü de erkek egemen yapısıyla öne çıkan ana sektörlerden biridir. Demokratik yaşamın ilerlemesine katkıda bulunan en önemli kurumlardan birisi olan medya sektörü içerisinde kadın gazetecilerin konumları ve yaşadıkları sorunlar incelenmesi gereken bir unsur olarak dikkat çekmektedir. Dolayısıyla bu çalışma Giresun ili yerel basınında çalışan kadın gazetecilerin sorunlarına odaklanmaktadır. Araştırma Giresun yerel basınında çalışan kadın gazetecilerin toplumsal cinsiyet, iş hayatındaki konumları ve yaşadıkları sorunları belirlemek amacıyla gerçekleştirilmiştir. Araştırmanın örneklemini Giresun ilinde yayımlanan 20 yerel gazete için çalışan sarı basın kartına sahip kadın gazeteciler oluşturmaktadır. Kadın gazetecilerin demografik yapısını, mesleki faaliyetlerini ve yaşadıkları sorunları kendi ifadeleriyle ortaya koymak amacıyla çalışmada derinlemesine görüşme tekniği kullanılmıştır. Erkek egemen yapının hakim olduğu Giresun yerel basınında, kadın gazetecilerin toplumsal cinsiyete dair bilinçli olmadıkları, iş hayatlarında cinsiyete dayalı mobbing ile karşılaşmadıkları ve yerel basınının profesyonel bir editoryal yapılanmaya sahip olmadığı tespit edilmiştir.

Anahtar Kelimeler: Toplumsal Cinsiyet, Yerel Medya, Kadın Gazeteciler.

\section{Position and Problems of Women Workers in Local Press: Example of Giresun Local Press}

\begin{abstract}
The concepts of gender and gender discrimination are fields of discussion in which different roles of femininity and masculinity are imposed in the cultural and socio-economic structure of the society in which individuals live. Especially in patriarchal societies, the living and working area of women is limited to the home by isolating then from the public space. In such social structures, male domination manifests itself in every layer of society. Gender discrimination makes itself felt in many different areas from family life to education life, from social life to business life. The media sector is one of the main sectors that stand out with its male-dominated structure. One of the most important intitutions contributing to the advancement of democratic life, the position of the women journalists in the media sector and their problems stand out as an element to be examined. Therefore, this study focuses on the problems of women journalists working in the local press of Giresun province. The research was carried out to determine the gender, job positions and problems of female journalists working in the local press of Giresun. The sample of the study consists of woman journalists with a yellow press card who are working for 20 local newspapers published in Giresun. In the study, in-depth interview technique was used in order to reveal the demographic structure, professional activities and problems of women journalists with their own words. In the local press of Giresun where the male-dominated structure is dominant, it has been determined that female journalists are not conscious about gender, don't encounter gender-based mobbing in their business life and local press doesn't have a professional editorial structure.
\end{abstract}

Keywords: Gender, Local Press, Women Journalists

Received/Geliș: 24.02.2020

Accepted/Kabul: 09.06.2020

Etik Kurul Başvuru Tarihi: 30.04.2020

Etik Kurul Rapor Tarihi: 11.05.2020

\footnotetext{
* Öğr. Gör., Giresun Üniversitesi Tirebolu İletişim Fakültesi Gazetecilik Bölümü, nedim.bilecen@giresun.edu.tr, nedimbilecen@gmail.com, (D//0000-0001-9533-8212,

(Makale türü: Araştırma Makalesi)
} 


\section{Giriş}

Günümüzde kadınların işgücüne katılımı konusunda geleneksel bir yapı hakimdir. Bu ayrımcı yaklaşım nedeniyle kadın öncelikli olarak eş, anne, ev kadınlığ gibi roller ile sınırlandırılmaktadır. Ataerkil kodlara sahip toplumlarda görülen cinsiyete dayalı iş ayrımcılı̆̆g, kadınların çoğunu toplumsal üretimin dışında bırakmakta ve kendilerine çocukluktan itibaren öğretilip içselleştirilen cinsiyet odaklı düşünce ve davranış kalıplarına zorlamaktadır.

Ülkemizde de ataerkil yapının hakimiyetinden kaynaklanan toplumsal cinsiyet eşitsizliği kadınların iş hayatına dahil olmasında sorunlu alanlardan biridir. Kadınların farklı iş sektörlerinde yeteri kadar yer bulamamalarının ana nedenlerinden birisi erkek egemen yapıdır. Erkek egemen toplum düzeni içinde kadın kendisine dayatılan rollerin dışına çıkarak var olmak istediğinde, halen erkeğin izni ve kontrolüne tabi olmakta ve bu durum çalışan kadınları ev içi ile sınırlamaktadır. Özellikle 20. yüzyıldan itibaren üretici olarak ekonomik yaşamın içine dahil olan kadın, işgücüne giderek yükselen bir katılım sağlamıştır. Bununla birlikte kadın işgücünün artması kadın haklarının tartışılmasını beraberinde getirmiştir. Ayrıca işlerin kadın işi ve erkek işi olarak ayrılması cinsiyet ayrımının iş yaşamında karşılaşılan en bariz göstergelerinden biridir. Çalışma hayatında kadının aleyhine erkeğin lehine gelişen toplumsal cinsiyet eşitsizliği cam tavan kavramı etrafında şekillenmiştir. Kavram örgütsel yapılarda, kadınların yöneticilik konumuna yükselmesine mani olan ya da kısıtlayan bir engeli ifade etmek için kullanılmaktadır. Cam tavanlar kadınların belli bir seviyenin üstüne çıkmasını engelleyen görünmez bariyerler olarak tanımlanırken, bu bariyerin kadınlara sırf kadın oldukları için uygulandığı varsayılmaktadır (Başak, 2009, s. 122).

Kadınların karşılaştıkları bu tip sorunlar medya sektöründe de karşımıza çıkmaktadır. Kadın gazetecilerin medya sektöründe erkek gazetecilere göre işgücünde eşit şekilde yer alamamaları ve aynı zamanda yönetici kadrolarına yükselmelerinde karşılaştıkları problemler beraberinde kadınların işgücündeki temsil sorununu ortaya çıkarmaktadır. Ulusal basında yaşanan bu temsil sorunu aynı zamanda yerel basının da kendini göstermektedir. Demokratik katılımın gelişmesine yardımcı bir araç rolü olduğu düşünülen yerel basında çalışan profili yine erkeklerin sayı olarak daha fazla konumlandığı bir yapıdan oluşmaktadır. Yapılan çalışmada bu anlamda feminist bir perspektiften ziyade yerel basındaki kadın çalışanların içinde bulundukları çalışma koşulları içinde yaşadıkları sorunları ve beklentilerini ortaya koymak amacını taşımaktadır. Dolayısıyla çalışma Giresun ili yerel basın kadın çalışanları ile sınırlandırılmıştır. Bu kapsamda basılı-dijital gazete çalışanları örneklem alınmış, farklı haber ajanslarının kadın çalışanları kapsam dışında bırakılmıştır. Araştırma kadın çalışanların sorunlarının gazetecilik pratiklerine nasıl yansıdı $\breve{g} 1$ konusunda bir değerlendirme sunacaktır. 


\section{Toplumsal Cinsiyet ve Çalışma Yaşamı}

Cinsiyet kavramı TDK' da "Bireye, üreme işinde ayrı bir rol veren ve erkekle dişiyi ayırt ettiren yaradılış özelliği, eşey, cinslik, seks" şeklinde tanımlanmaktadır. Bu anlamda cinsiyet, kadın ve erkek arasındaki doğal farklılıkları işaret eder. Toplumsal cinsiyet kavramı ise kadınlık ve erkekliğin toplumsal olarak nasıl kurulduğunu ifade eder. Yani kadın ve erkeğin sosyal olarak belirlenen rol ve sorumluluklarıdır. Toplumsal cinsiyet eşitliği ise genel olarak kadınların ve erkeklerin toplumsal yaşamın her alanına eşit katılımını ifade eder. Başka bir anlatımla kadın ve erkeklerin eşit hak ve imkanlara sahip oldukları durumları işaret eder (Kara, 2019).

Toplumsal cinsiyet eşitliği kadınların ve erkeklerin eşit değere sahip olduklarını ve eşit şekilde muamele görmeleri gerektiğine vurgu yapar. Buradaki eşitlik kavramı ise; kadın-erkek her bireyin sosyal, siyasal ve ekonomik her alanda eşit olanaklara sahip olması demektir. Ancak her dönem ve toplumda türlü çalışma biçimleri ile üretim etkinlikleri içerisinde yer alan kadınların iş bölümündeki çeşitlilik, çalışma nosyonuna erkekler ve kadınlar açısından farklı bir anlam ve içerik yüklemektedir. Özellikle kadınların çalışma hayatına katılımının sadece ekonomik olarak üretken faaliyetlerden oluşmaması nedeniyle mevcut çalışma şartlarını kadın ve erkek için farklı şekilde biçimlendirmektedir. Bu açıdan feminist kuramcılar cinsiyetler arasındaki eşitsizliği reddederek kadınların hayatını olumsuz yönde etkileyen koşulları eleştirmektedirler. "Sosyalist feminizm, bu koşulları tarihsel olarak ele alması bakımından diğer feminist akımlardan ayrllmakta ve konuya eşitsizliklerin kaynağı olarak gördüğ̈̈ 'ataerkil kapitalist' sistemi eleştirmekle başlamaktadır” (Özdemir, 2017, s. 397).

Erkeklerin kadınların çalışması üzerinde sahip oldukları kontrolü vurgulamak üzere kullanılan ataerkil kapitalizm kavramında ataerkillik kadınların sadece çocuk doğurma ve yetiştirmeye yönelik rollerine yönelik bir kavram olarak değil aynı zamanda erkeklerin kapitalist sistem içerisinde kadınların emek gücünü denetim altında tuttukları toplumsal organizasyonlar olarak değerlendirilmektedir (Çetinel \& Y1lmaz, 2016, s. 132). Ayrıca sosyalist feministlere göre Marksist düşünce tek başına bir ekonomik üretim tarzı kuramı olarak kadınların yalnızca ekonomik olarak nasıl sömürüldüğünü açıklayabilmektedir. Radikal feminizmin ataerkillik kavramı ise kadınlara yüklenen roller ve dayatmalar hakkında daha geniş kapsamlı açıklama getirebilen bir kuram olarak görülmüştür. Dolayısıyla bu iki kuramın birleştirilmesiyle ortaya çıkan "kapitalist ataerkillik" kavramı erkek egemen pratiklerin, toplumsal ilişkilerin, ideolojilerin ve düşünce yapılarının aile içinde ve dışındaki ekonomik sömürüyü nasıl artırdığını açıklamak açısından oldukça önemlidir (Berktay, 2011).

Bununla birlikte kadının iş yaşamının bir parçası olarak özel alanın yanı sıra kamusal alanda da varlık göstermeye başlaması bile erkeklerin kadınlar üzerine kurdukları baskıları ve kadınların toplumdaki ikincil konumunu değiştirmemiştir. Aksine kadınlara uygulanan baskılar 
daha da yoğunlaşmıştır. Çünkü kadınlar toplumsal emek gücünün bir parçası olarak özgürleşmek yerine iki iş birden yapmak zorunda kalmışlardır: kamusal alanda ücret için çalışmak, fakat özel alanda ücretsiz ev içi işi yapmaya devam etmek (Donovan, 2014, s. 166). Toplumdaki eşit olmayan cinsiyete dayalı iş bölümü ise çalışan kadınların omuzlarındaki yük altında daha fazla ezilmesine yol açar; bir yandan evde ücretsiz ev içi emeklerine eşleri tarafından el konulmaktadır, diğer yandan ise cinsiyet ayrımcılığının yaygın olduğu üretim piyasalarında düşük ücretli, düşük pozisyonda mavi ve beyaz yakalı işlere mecbur bırakılarak ezilirler (Berktay, 2011). Sosyalist feministler bu durumun sebebini cinsiyete dayalı iş bölümüne dayandırmaktadır. Onlara göre kadınların ve erkeklerin kendilerine uygun görülen rol kalıplarının bir uzantısı olarak farklı işlerde, endüstrilerde ve örgütsel seviyelerde çalışacakları bir yapı olan cinsiyete dayalı işbölümü kapitalist toplumun tipik bir özelliğidir. Bunun da ötesinde sosyalist feminist teorisyenler açık bir erkek ve kadın işi ayrımının olduğunu ve kadınların erkeklere oranla daha düşük ücretlerle, daha alt pozisyonlarda çalıştıııldıklarını iddia etmektedirler (Holvino, 2010).

Toplumsal cinsiyete dayalı iş bölümü, erkek egemen yapının kurallarını belirler ve ataerkil ilişkiler çalışma yaşamında farklı şekillerde kadınlara dayatılır. Kadınların maruz kaldıkları toplumsal cinsiyet eşitsizliğine dayalı benzer sorunlar medya sektöründe de kendini açıkça göstermektedir. Kadınların sektör içerisinde kendilerine daha fazla yer bulmalarına karşın, medyadaki erkek egemen yapı henüz aşılabilmiş değildir (Arslan \& Arslan, 2017, s. 218-219). Gazetecilik mesleği ve medyanın tüm bileşenleriyle kamusal alanın merkezinde olması, bu alanın erkek alanı olmasını açıklayıcı niteliktedir. Medyanın cinsiyetçi yapısı, bu sektörde çalışanların içinde bulundukları profesyonel ideolojiden kaynaklanmaktadır. Medya kadını iki kalıp yargı içinde kullanmaktadır. Birincisi ataerkil yapı içinde kadının geleneksel yapı tarafından benimsetilen anne, eş, ev kadını gibi roller içine konumlandırılması, ikincisi ise ilgi çekme, daha çok izlenme ve sansasyon kaygılarına boyun eğme şekliyle kadın bedeninin sergilenmesi. Kadının bu kalıplara indirgenmesi yanında, kadına yönelik mesleki ayrımcılığın en fazla yaşandığı alanlardan biri de medya sektörüdür (Timisi, 1997 aktaran Tekvar, 2016, s. 435-436).

\section{Yerel Basın}

Türkiye İstatistik Kurumu'nun (TÜİK) Temmuz 2019 yılında yayınladığı yazılı medya istatistiklerine göre; Türkiye'de yayımlanan gazetelerin \% 91,3'ü yerel, \% 6,9'u yaygın (ulusal) ve $\% 1,8$ 'i ise bölgesel yayımlanmıştır. Dergilerin ise, \%64,3'ü yaygın (ulusal), \%31,4'ü yerel, \%4,3'ü bölgesel yayım yapmıştır. Gazetelerin toplam tirajının \%81,6'sı yaygın (ulusal), \%17,6's1 yerel ve \%0,7'sini bölgesel yayımlanan gazeteler, dergilerin ise \%75,6's1 yaygın (ulusal), \%20,9'u yerel ve \%3,6'sını bölgesel yayımlanan dergiler oluşturmuştur (TÜİK, 2019). Yayımlanan gazetelerin \% 91,3'ünün yerel yayın yaptığı düşünüldüğünde yerel basının önemi, işlevi ve yaşadığı sorunların tespiti oldukça önemlidir. Toplumsal, ekonomik, kültürel ve sosyal 
gelişmeleri yakın çevrede yaşayan bireylere aktaran yerel basın, içinde konumlandığı toplumun ekonomik, kültürel, sosyal ve siyasal özelliklerini yansıtan bir ayna gibidir. "Yerel basin organlart bireylerin, kendi şehir ve beldelerindeki sorunlar, olaylar, ekonomik ve sosyal gelişmeler ve yerel yönetimlerin aldı̆̆ı kararlar hakkında bilgi sahibi olmaları açısından son derece önemlidir. İletişimciler yerel basinı, otoritenin merkezden uzaklaşmasına ve insanı gözeten bir yapının yaratılmasına olanak sağlayan dinamik bir unsur olarak görmektedirler", (Gezgin, 2007, s. 177).

Yerel basına çoğunlukla liberal öğretiye dayanan bilgilendirme, öğretme, demokratik katılımın sağlanmasında öncülük yapma, yerel yönetimleri denetleme, yerel kültürel mirasın ve farklılıkların korunması gibi görevler yüklenmektedir (Şeker, 2007, s. 66). Bu önemli görevleri yerine getirmesine rağmen yerel basının günümüzde birtakım sorunlar ile mücadele ettiği yadsınamaz bir gerçektir. Reklam gelirlerinin ulusal basına göre neredeyse yok denecek kadar az olması, tirajların düşüklüğü, nitelikli personelin az olması, sahiplik yapısı ve ajansa bağımlı yayıncılık sorunlar arasında öne çıkanlardır. Bunlarla beraber Nalcığlu (2007, s.198) yerel basının işlevlerini yerine getirirken uğraştı̆̆ farklı sorunlarını teknolojik, ekonomik, etik, yönetim organizasyon ve insan kaynakları olarak sıralamıştır. Ayrıca yerel basında ulusal basında olan uzmanlaşma alanları olmadığı için, çalışan muhabirler polis-adliye, spor, kültür-sanat, ekonomi gibi farklı türlerde haber yapmaktadır. Oysa yerel basında çalışan sayısının az olması bölümlerin çeşitlenmesi kadar bağımsızlığını da doğrudan etkilemektedir. Muhabirler her türlü habere gönderildikleri için örgüt içindeki hiyerarşik yap1 biçimsel olmayan ilişkilere dönüşebilmektedir (Eroğlu \& Arslan, 2017, s. 272).

Yerel basının taşıdığı toplumsal sorumluluk bağlamında üstlendiği görevler düşünüldüğünde yönetim ve organizasyon yapısının uyumlu olması beklense de, ulusal basının temel sorunlarından birisi olan cinsiyete dayalı ayrımcılık yerel basında da kendini gösterir (Arslan \& Arslan, 2017, s. 223). Kadın çalışan sayısının erkeklere oranla çok düşük olması, mobbing, taciz, ücret politikasındaki eşitsizlik kadın çalışanların bu sektörde yaşadığı sorunların başında gelmektedir. Yapılan çalışmada da Giresun ili özelinde yerel basında çalışan kadınların karşılaştıkları sorunları ortaya koymak ve tartışmaya açmak amaçlanmaktadır.

\section{Araştırmanın Amacı ve Varsayımları}

Yerel basında çalışan kadınların sorunları, gazetecilik mesleğine bakış açıları ve sorunlarını ortaya koymak bu çalışmanın ana amacını oluşturmaktadır. $\mathrm{Bu}$ amaç doğrultusunda araştırma ve yayın etiği göz önünde bulundurularak aşağıda verilen problemler Giresun ili yerel basınında çalışan kadın gazeteciler özelinde irdelenmiştir;

- Birçok farklı sektörde olduğu gibi yerel basında da ataerkil bakış açısıyla işgücü rolleri dağıtılmaktadır. 
- Yerel basında kadın çalışanların işgücüne katılımında eşitlik söz konusu değildir.

- Yerel basında kadın çalışan olmak dezavantajlı bir durumdur.

- Yerel basında maaş konusunda kadınlara karşı bir dengesizlik söz konusudur.

- Kadınların yerel basında yönetici olma noktasında çeşitli engeller bulunmaktadır.

\section{Araștırmanın Yöntemi}

Çalışmada araştırmaya temel oluşturan kuramsal bilgilerin yer aldığı literatür taraması ile birlikte kuramsal çerçeve kapsamında toplumsal yaşam için önemli bir araç olan yerel basın ve yaşadığı sorunlar ele alınmıştır. Sorunların ve bu sorunların algılanmasının doğal ortamda gerçekçi ve bütüncül bir biçimde ortaya konmasına yönelik olarak tasarlanan çalışmanın uygulama aşamasında ise Giresun ili yerel basınında çalışan kadınlara yönelik demografik yapıları ve mesleki etkinliklerine dair yarı yapılandırılmış sorular hazırlanarak derinlemesine görüşmeler gerçekleştirilmiştir. Ayrıca yapılan görüşmeler ile kadın çalışanların yaşadıkları zorlukları ve karşılaştıkları sorunları kendi ifadeleri ile dile getirmeleri sağlanmıştır. Ayrıca taciz vb. hassasiyet içeren sorularda sorun yaşanmaması için görüşmeleri kadın gazeteci adayları (Gazetecilik bölümü son sınıf öğrencileri) gerçekleştirmiştir. Basılı-dijital olarak yayınlanan gazete çalışanlarının örneklem olarak alındığı çalışmada haber ajanslarının kadın temsilcileri kapsam dışında bırakılmıştır. Gönüllü oldukları yazıyla onaylatılmış 9 kadın gazeteci ile yapılan görüşmeler her bir kadın gazeteciyle yaklaşık iki saat sürmüş, kadın gazetecilerin çalıştıkları kurumlarda yapılmış ve elde edilen gözlem verileriyle daha ayrıntılı bilgilere ulaşılmıştır.

\section{Bulgular ve Yorum}

\section{Giresun Yerel Basınının Konumu}

Çalışma kapsamında Basın İlan Kurumu'ndan elde edilen verilere göre kentte resmi ilan alan ve basıl1-dijital olarak yayın hayatına devam eden 20 gazete bulunmaktadır. Bunlar; Giresun Ekspres, Yeni Giresun, Giresun İleri, Yeşil Giresun, Yeşil Çotanak, Son Baskı, Gündem, Sonses, Takip, Gazete Savaş, Yöremiz, Sisdă̆ , Karadeniz Postası, Derelinin Sesi, Yıldız Haber, Giresun Öncü, Yenişebinkarahisar, Bizim Piraziz, Bizim Dereli ve Aktif Haber'dir. Bu gazetelerde sarı basın kartına sahip 57 erkek ve 17 kadın gazeteci bulunmaktadır. Sisdağı, Giresun Öncü, Yeşil Giresun, Gündem, Sonses, Bizim Piraziz ve Takip gazetelerinde çalışan hiçbir kadın gazeteci ise bulunmamaktadır. Bu veriler ışığında Giresun ili yerel basınında erkek egemen bir yapılanma olduğu görülmektedir. Yapılan çalışmaya farklı görevlerde çalışan toplam 17 kadın gazeteciden 9'u araştırmaya gönüllü olarak katılmışlardır. Görüşmeler esnasında gazetecilerin cevapları kendi izinleri doğrultusunda ses kayıt cihazında kayıt altına alınmış ve sonra deşifre edilmiştir. Görüşmeler kapsamında evli ve çocuklu gazetecilere farklı sorular yöneltilerek elde edilen bulguların kapsamı genişletilmiştir. Ayrıca görüşmeler araştırmaya katılanların çalışma ortamlarında yapılarak iş hayatlarına dair gözlemler yapılmıştır. Bu gözlemler sırasında dikkat 
çekici ayrıntılardan birisi görüşmelerin yapıldığı mekanların tamamının matbaa olmasıdır. Yerel basın içinde faaliyet gösteren bu gazetelerin bağlı olduğu şirketler aynı zamanda baskı sektörünün diğer alanlarında da (davetiye, kartvizit, afiş, poster vb.) faaliyet göstermektedir. Dolayısıyla Giresun ili yerel basınında profesyonel bir editoryal yapılanmanın olmadığı açıkça görülmektedir.

\section{Kadın Gazetecilerin Demografik Yapısı}

Giresun yerel basınında çalışan kadın gazetecilerin yaşları Şekil 1'de görüldüğüü üzere, 6 gazeteci 20-35 yaş aralığında, 3’ü ise 36 yaş ve üstüdür. Bu anlamda çalışan kadın gazetecilerin genç kuşak gazeteci neslini temsil ettiği söylenebilir.

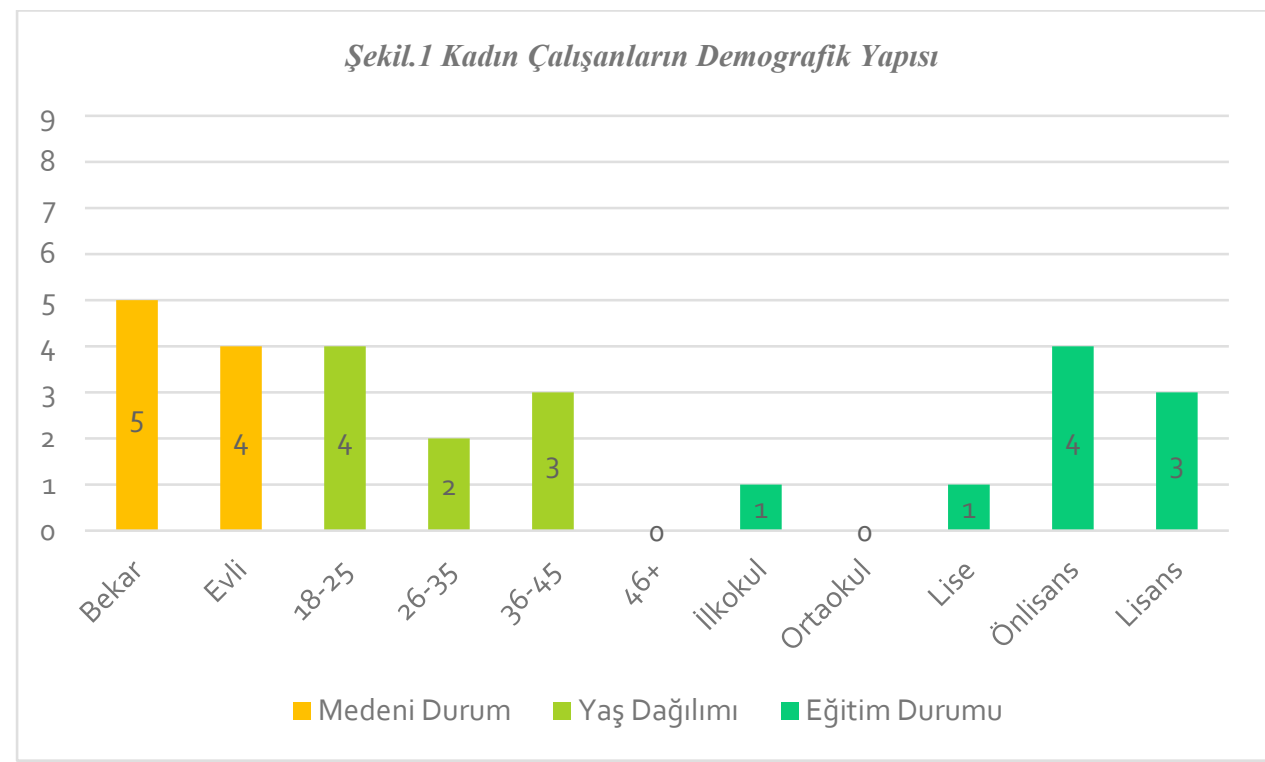

Kadın gazetecilerin eğitim durumları sorgulandığında ise 3'ü lisans, 4'ü ön lisans, 1'i lise ve 1 kişinin ise ilkokul mezunu olduğu görülmektedir. Ön lisans mezunlarından 2 gazeteci Radyo Televizyon Yayımcılığı ve Halka İlişkiler mezunu olduklarını ifade etmiştir. Genel olarak Giresun yerel basınındaki kadın gazeteciler eğitimli olmalarına rağmen mesleki eğitim almış kişilerin alanda aktif olarak istihdam edilme oranının az olması dikkat çekmektedir. $\mathrm{Bu}$ da özellikle yerel basının önemli sorunlarından birisi olan mesleki eğitimli insan gücü sorununun Giresun ili bazında da yaşandığını göstermektedir. Deneyim noktasında ise çalışmaya katılan kadın gazetecilerin önlisans mezunu olan ikisi yaklaşık 2 yıldır gazetecilik mesleğini yaptıklarını diğer 7 kadın gazeteci ise 5 yıldan daha uzun süredir sektörde çalıştıklarını beyan etmişlerdir.

Çalışmaya katılan 9 kadın gazeteciden 5'i evli, 4'ü ise bekâr olduğunu belirtmiştir (Şekil 1). Evli olduğunu belirtenlerin 4 tanesi 1, 1 tanesi ise 2 çocuğa sahiptir. Bu noktada evli ve çocuğu olan kadın gazetecilere mesleki pratiklerini yerine getirmelerinde bu durumun sorun oluşturup oluşturmadığı sorulmuştur. Genel olarak evli olan 5 kadın gazeteci de çocukların belli bir yaşa kadar anneye ihtiyaçları olduğunu, çocukların fizyolojik bakımı ve güvenliğiyle ilgilenmek 
durumunda olduklarını ancak mesleğin getirdiği zorunluluklar nedeniyle bu görevin babaya düştüğünü söylemiştir. Evli ve çocuğu olan 3 kadın gazeteci eşlerinin çalışma saatlerinin kendilerinin aksine daha belirli olması nedeniyle bu noktada yardımcı olduklarını belirtmişlerdir. 2 kadın gazeteci ise eşlerinin esnaf olması sebebiyle çocuk bakımı konusunda yardım aldıklarını ifade etmiştir.

Özellikle verilen cevaplarda dikkat çeken unsur ise kadın gazetecilerin işten eve dönüşlerinde kendilerine ait olduklarını düşündükleri ev içi işler konusunda zorunluluk hissetmeleri ve bu konuda herhangi bir destek almamalarıdır. Bu noktada kadınların iş hayatlarındaki konumlarıyla beraber özellikle ataerkil toplumlarda kendilerine biçilen "ev kadınlı̆̆ı" ve "annelik" rollerinin de Giresun ilinde çalışan kadın gazeteciler için baskın bir yapı olduğu söylenebilir. Ancak bu noktada bir konuya parantez açmak yerinde olacaktır. Görüşmeler esnasında gözlemlenen önemli ayrıntılardan bir tanesi de, kadın çalışanların hem kendileri hem de diğer kadınlar için genellikle "bayan" ifadesini kullanmasıdır. Dolayısıyla kadın gazetecilerin toplumsal cinsiyet eşitliği bağlamında yeterli ve ortak bir bilince sahip olmadıkları söylenebilir.

\section{Kadın Gazetecilerin Mesleğe Dair Değerlendirmeleri}

Giresun ili yerel basınında çalışmaya katılan kadın gazeteciler uzmanlaşma olmaması nedeniyle birçok farklı haber türünde görevlendirildiklerini ve kadın-erkek gazeteci arasında bu noktada herhangi bir ayrım yapılmadığını belirtmişlerdir. Ancak birçok sektörde olduğu gibi basında da kadınlara karşı olumsuz bir önyargının varlığından bahsetmişlerdir; "Ben kendi açımdan söylersem. Mesela bir yerde bir toplantı var. Ya da bir görüşme var diyelim. Bayan olarak o ortama girdiğinde ister istemez çekiniyorsun ortamda çok fazla erkek olduğu için. Yani bir çekingenlik durumu yaşanıyor. Türkiye bazlı düşünürsek, erkekler tabi daha baskın karakterli olduğu için ciddiyete almama olayı illa ki var yani. Kadındır bilmez, ne bilebilir ki? Böyle sıkıntılar olduğunu düşünüyorum. Otorite kurma durumu var. Erkek olsa yaklaşımları farklı olur ama bayan olduğu için bir ciddiyete almama durumu var (G1)*. Konuyla ilgili olarak G3 ise "Kadın olarak çalışmak, küçük şehirlerde, illerde daha slkıntılı. Sizi önemsemiyorlar. Fikirlerinize değer vermiyorlar. Hep ön planda erkekler olmak istiyor. Her şeyi ben yaptım demek istiyor. Büyük bir bencillik var, kadınlar konusunda. Her şeyleri kendileri yapmak istiyorlar. Ama kadınsız bir hayatları yok. Kadınların daha başarılı olduğunu düşünüyorum” sözleriyle düşüncesini belirtmiştir.

Bununla beraber çalışmaya katılan kadın gazeteciler gelir durumu açısından herhangi bir ayrımcılık yapıldığını düşünmemektedirler. Bu durum birçok farklı sektörde kadın-erkek çalışanlar arasındaki maaş dengesinin eşit olmadığı durumlar düşünüldüğünde Giresun yerel

\footnotetext{
* Etik kurallar göz önünde bulundurularak görüşmeciler (G1-G2-G3 ....) şeklinde kodlanmıştır.
} 
basını için olumlu bir durum olarak karşımıza çıkmaktadır. Ayrıca kadın gazeteciler var olan çalışma koşullarından genel olarak memnun olsalar da hiçbiri yaygın basında çalışmamalarına rağmen genel olarak şartların kendileri için çok daha iyi olacağını ve ulusal gazetelerde yükselmelerinin çok daha kolay olacağını düşünmektedir. Ancak G9, yerel basının da kendi içinde bazı avantajları olduğunu ifade etmiştir; "Bence yerel medya daha iyi. Daha küçük olduğu için. İstediğim zaman çıkabiliyorum. Önemli bir şey olsa gidebiliyoruz. Çalışan bir anne olduğum için yerel medya daha iyi. Şu anda eşimin iş saatleri bana pek uymuyor çocuk açısından. Ama uysa da bir sıkıntıyla karşılaşmam. Patronlarımız să̆ olsun o konuda hiçbir kısıtlama getirmiyorlar bize. Rahatım burada. Aile ortamı var burada. Yaygın medyada çalısssaydım daha resmi olduğu için eminim sıkıntılar yaşayabilirdim. İzin ve çocuğum konusunda kesinlikle sıkıntı yaşardım. Çocuğum çok küçük olduğu için sürekli hastalanıyor ve aşısl, kontrolü ve ıvır zıvırı olabiliyor. Eminim buradaki gibi çıkıp gidemezdim. Çocuk açısından yerel medya benim için daha iyi."

Durumla ilgili G7 ise, "Yerel medya küçük yer. Çalışma koşulları daha uygun. Ulusal medya büyük yer daha çok sahaya açıllyorsun. Bana bu konuda yerel medya daha iyi geliyor. Mevkii olarak ulusal daha havalı durabilir ama yerelde şöyle bir şey var. Habere gittiğinde pek tanıdık insanlarla karşılaşıyorsun. Küçük yer olduğu için sıkıntı çekmiyorum ama ulusalda olsam kesin çekerdim ama. Hem çalışma saatleri hem de ortamımız çok iyi. Bu yüzden insan daha çok severek yaplyor. Ulusal daha zordur. Daha çok yere açıllyorsun. Habere gidiyorsun. Ben ulusal medyada çalışmak istemezdim. Aslında yapacağım işe bağlı. Bir muhabir olarak asla istemezdim. Çünkü bir habere gidiyorsun. Hep erkek egemenliğinin olduğu yerler. Sirf erkeklerin olduğu bir yere girdiğinde ben rahatsız olurum şahsen. Mesela sırf erkeklere ait bir kongre haberine gittiğimi düşünürsek. Orada bakışlardan rahatsı olurum. Tek bir kadın olarak orada öne çıkıyorsun ya sanki ilk defa kadın görmüş gibi bakanlarda olur ve bu da beni rahatsız eder", sözleriyle yerel basının kendi açısından sağladığı avantajların altını çizmiştir.

Kadın gazeteciler genel olarak ulusal basında mesleki açıdan yükselmelerinin daha kolay olacağını ifade ederek aslında kurumsallaşmış bir yapıda çalışmanın avantajlarına vurgu yapmışlardır. Ancak özellikle küçük bir yerde çalışmanın kendilerine getirdiği avantajları da dile getirmişler ve bu anonim yapı kadın çalışanlar için öne çıkan bir unsur olarak dikkat çekmiştir.

\section{Kadın Gazetecilerin Meslekteki Cinsiyet Eşitliğine Dair Görüşleri}

Günümüzde gazetecilik koşullarında rekabet oldukça ön planda olan bir unsurdur ve bu durum genellikle gazetecilerarasındaki ilişki durumunu etkilemektedir. Bu konuda yapılan sorgulamada Giresun yerel basınında çalışan kadın gazeteciler erkek meslektaşları ile dayanışma içinde olduklarına yönelik bildirimde bulunmuşlardır. Ayrıca kadın gazeteciler, çocuk ile ilgili acil durumlarda, doğum, yakınlarının ölümü ve sağlık problemleri gibi izin kullanımı gerektiren 
konularda da yasal haklarından yararlandıklarını ifade etmişlerdir. Bu anlamda çalışmaya katılan kadın gazetecilerin hepsinin yöneticisi erkek olmasına rağmen herhangi bir mobbinge uğramadıkları göze çarpmaktadır.

Kadın gazeteciler, genel olarak kadınların medya sektöründe daha fazla yer almamalarının toplumsal olarak yaratılan "gazetecilik mesleği kadınlar için zor bir meslek" algısından kaynaklandığını belirtmişlerdir. Konuyla ilgili olarak G4; "Toplumda bayanlara yönelik kırılmayan tabular var. "Kadın, yani kadın başına mesela ben gazete bile dağıttım yeri geldiği zaman. Gazete dă̆ıtmak başlı başına asla ayıp bir şey değildir. Gazete dă̆ıtırken şununla çok karşılaştım. Kısa bir dönemde elemanımı mevcut değildi. Yeri geliyor her şeyi yapmak zorunda kalabiliyorsunuz. Bu iş yerinde bir çalışma yani ekip çalışması bu. Ve gazete dă̆ıtmam gerekti dağıttım. Mesela o zamanlar sana mı kaldı, sen bayansın gibi tuhaf karşılamalar çok fazla oldu. Yani toplumda bayan olduğu için o kırllmayan tabular mevcut. Belki de burası küçük bir yer olduğu için de olabilir. Erkek yapması gerekir gibi düşünce var yani çoğu yerde. Yani habere gitme konusunda da olabilir böyle şeyler. Sanki bayan böyle çok fazla iş yapamaz, erkek yapsın gibi bir algı her yerde var" sözleriyle durumu betimlemiştir.

Ayrıca kadın gazetecilerin yönetici olarak yükselememesinin nedeni olarak da kadınlara yeterince fırsat verilmediğini ve bunun temelinde de kadınların çalışma hayatındaki konumlarına dair kalıplaşmış yargıların yattığını ifade etmişlerdir. "Bence bu durumda biraz kadınlara firsat verilmeli. Onları çalıştırıp ne kadar başarılılar, değiller, ne kadar bu işi yapabiliyorlar? Bence bu değerlendirilmeli. Ön yarglyla yaklaşılmamalı bu konuda kadınlara. Kesinlikle onlara da birazcık firsat verilmeli diye düşünüyorum. Fırsat verilip bakılabilinir. Kadınlar başarılı zaten. Yani o önyargılarını yıkamıyorlar. Ön yargılarını yıksalar olacak” (G3). Konuyla ilgili G6 ise düşüncelerini şu şekilde belirtmiştir; "Evet, genelde yöneticiler erkek. Değişmesi için kadın yöneticilerin olması lazım. Daha çok kadın girişimcilerin olması gerek. Kadınlara daha çok teşvik verilmesi gerek. Kadınlar ön planda olmall, ticarete atılmall. Diğer bütün mesleklerde de bu böyle. Genelde bütün mesleklerde yönetici konumunda olanlar erkek. Bayanlar her zaman ikinci planda oluyorlar. Daha çok erkek baskın. Hele bu küçük yerlerde daha çok. Bayanlar genelde ev hanımı gözüyle bakılır. Bir yerde bir bayan olduğunda farklı bakılabilir erkekler veya büyük yaşlılarımız tarafindan". Ancak çalışmada yer alan 9 kadın gazeteci kendilerinin bu algıyı kırmak için mücadele verdiklerinin altını çizmiştir.

Toplumsal cinsiyet eşitsizliği bağlamında kadınların meslek yaşantılarında karşılaştıkları önemli sorunlardan bir diğeri de tacize uğramalarıdır. Türkiye Gazeteciler Sendikası (TGS) Kadın ve LGBTİ Komisyonu'nun (TGS, 2018) yayınladığı raporda medyanın erkek egemen ortamında çalışan kadınların karşılaştıkları sorunlar ortaya konmuştur. Rapora göre çalışmaya katılan 168 kadın gazeteciden yüzde $15.5^{\prime}$ i (26) fiziksel ve yüzde 8.9'u (15) ise dijital tacize uğradıklarını 
belirtmişlerdir. Fakat Giresun ili kapsamında yapılan bu çalışmada tacize dair olumsuz bir durumla karşılaşılmamıştır. Araştırmaya katılan kadın gazeteciler taciz ile ilgili ülke çapında yaşanan genel bir problemin olduğunu ve yerelde de zaman zaman bu tip olaylarla karşılaşıp haberleştirdiklerini söylemelerine rağmen ne iş yerinde meslektaşlarından ne de haber kaynakları tarafından tacize uğramadıklarını belirtmişlerdir.

\section{Sonuç ve Öneriler}

Yapılan çalışmanın temel amacı yerel basında görev yapan kadın gazetecilerin demografik yapılarını, sektörde yaşadıkları sorunları ve beklentilerini ortaya koymaktır. Bu amaç doğrultusunda elde edilen bilgiler ışığında cinsiyet eşitliğinin olmadığı Giresun ili yerel basınının erkek egemen bir yapıda olduğu belirlenmiştir. Genç nesil gazetecilerin temsil ettiği Giresun yerel basınındaki kadın çalışanların eğitim seviyelerinin ise yüksek olduğu tespit edilmiştir. Ancak sektörle ilgili eğitim almış kadın gazetecilerin sadece iki tane olması özellikle yerel basının genel problemlerden birisi olan mesleki eğitimli işgücünün istihdam edilmemesinin Giresun yerel basınında da yaşandığını göstermiştir. Bu noktada görüşmeler esnasında yapılan gözlemlerde dikkat çeken bir ayrıntıya vurgu yapmak yerinde olacaktır. Görüşmeler kadın gazetecilerin çalıştıkları iş yerlerinde yapılmıştır. Ancak bu mekânların tamamı matbaadır. Yerel basında yayımlanan gazetelerin bağl1 olduğu şirketler bask1 sektörünün davetiye, kartvizit, afiş, poster vb. farklı alanlarında da faaliyet gösterdiği için Giresun ili yerel basınında profesyonel bir editoryal yapılanmanın olmadığı görülmektedir.

Sektörde kadın olarak çalışmanın avantajları ve dezavantajlarına bakıldığında ise izin gerektiren durumlarda küçük bir yerde çalışmanın avantajı ön plana çıkmaktadır. Özellikle evli ve çocuğu olan 5 kadın gazeteci çocuklarının bakımı ve hastalık gibi durumlarda izin almakta sorun yaşamadıklarını söylemişlerdir. Ayrıca kadın gazeteciler daha iyi bir kariyer için kurumsallaşmış ulusal basında çalışmanın avantaj olduğunu düşünse de yerelde olmanın da kendilerine farklı avantajlar sunduğunu dile getirmişlerdir. Dezavantaj olarak göze çarpan unsur ise kadınların ev ve iş hayatı arasındaki dengeyi sağlamakta yaşadıkları sıkıntılardır. Evli olan kadın gazetecilerin dile getirdiği bu durum diğer iş alanlarında olduğu gibi basın sektöründe de kadınların ev ve iş hayatı arasında birtakım ikilemler yaşamak zorunda kaldığını göstermektedir. Elbette söz konusu durum toplumsal yapının kadın için dayattığı rollerle doğrudan ilgilidir.

Haber üretim süreci sorgulamasında kadın gazeteciler, erkek meslektaşları tarafından ayrımcılığa maruz kalmadan, dayanışma içinde olduklarını ifade etmişlerdir. Ancak 3 kadın gazeteci özellikle gittikleri haber ortamlarında çok fazla erkek meslektaşları olması nedeniyle yeteri kadar ciddiye alınmadıklarını söylemişlerdir. Çalışma koşulları bağlamında ise kadın çalışanlar maaş konusunda herhangi bir eşitsizlik olmadığını ve hepsinin yöneticisi erkek olmasına rağmen mobbinge uğramadıklarını dile getirmişlerdir. Farklı iş kollarında yaşanan ücret 
dağılımındaki eşitsizlik ve mobbing sorunlarının Giresun yerel basınında yaşanmadığı söylenebilir. Ulusal basında çalışmanın kariyerleri açısından önemli bir basamak olduğunu düşünseler de genel olarak yerel basında çalışmanın daha resmiyet gerektirmesi, çalışılan sahanın daha büyük olması ve çalışma saatlerinin belirsizliği gibi dezavantajları olduğunu belirtmişlerdir. Kadınların meslek hayatlarında karşılaştığı toplumsal cinsiyet bağlamındaki en büyük sorun şüphesiz taciz olayıdır. Ancak çalışmaya katılan kadın gazetecilerin hiçbiri ne iş yerinde meslektaşlarından ne de haber kaynakları tarafından tacize uğramadıklarını belirtmişlerdir. Haberleştirmek için birçok taciz olayıyla karşılaştıklarını belirtmelerine rağmen kendilerinin böyle bir durumla karşılaşmamış olmaları Giresun yerel basını için olumlu bir durum olarak öne çıkmaktadır.

Çalışma sonunda elde edilen bulgular 1şığında Giresun yerel basınında iyileştirilmesi gereken sorunlar şunlardır;

- Basın sektöründe çalışan kadın sayısının artırılarak erkek çalışanlarla eşit bir ortamın yaratılması gereklidir. Giresun ili özelinde faaliyetini sürdüren tüm yerel basın kuruluşlarının kadın gazeteci istihdam etmeleri sağlanmalıdır.

- Yerel basında nitelikli eleman sayısını artırmak için mesleki eğitim almış kişilerin daha fazla istihdam edilebilmesi için gereken yasal düzenleme yapılmalıdır.

- Giresun yerel basınında çalışan gazetecilerin tamamına yönelik toplumsal cinsiyet konusunda eğitim seminerleri düzenlenerek belirli bir bilinç düzeyi kazandırılmalıdır.

- Gazetecilik mesleğinin profesyonel bir editoryal yapılanmaya olan ihtiyacını karşılamak üzere Giresun yerel basınındaki gazetelerin gerekli düzenlemeleri yapmaları gerekmektedir.

Sonuç olarak yapılan bu çalışma Giresun ili yerel basınında cinsiyet eşitliği olup olmadığını ve kadın gazetecilerin yaşadıkları sorunları tespit etmeye yönelik girişimlerden birini oluşturmaktadır. Karadeniz Bölgesinin farklı şehirlerinde benzer çalışmalar veya karşılaştırmalar yapılarak alana kuramsal anlamda daha fazla katkı sağlanabilir. 


\section{Kaynakça}

Alyakut, Ö. (2018). Kadın Gazetecilerin Sosyal Hakların Uygulanmasına Yönelik Görüşleri: Kocaeli Medyası Örneği. 1. Uluslararası Eğitim ve Sosyal Bilimlerde Yeni Ufuklar Kongresi Bildiriler Kitabı (s. 21-30). İstanbul: Uluslararası Bilimsel Araştırmalar Dergisi.

Arslan, E., \& Arslan, B. (2017). LOCAL PRESS AND WOMEN WORKERS IN THE CONTEXT OF GENDER INEQUALITY. CURRENT DEBATES IN PUBLIC RELATIONS CULTURAL \& MEDIA STUDIES, 9, 217-238.

Başak, S. (2009). Cam Tavanlar. KÖK Sosyal ve Stratejik Araştırmalar Dergisi, XI(2), 119-132.

Berktay, F. (2011). Feminist Teoride Açılımlar. Toplumsal Cinsiyet Çalışmaları. içinde Anadolu Üniversitesi Yayınları.

Çetinel, E., \& Yılmaz, S. E. (2016). Feminist Teori: Yönetim Ve Organizasyon Alanına Eleştirel Bir Yaklaşım. Çankırı Karatekin Üniversitesi İktisadi ve İdari Bilimler Fakültesi Dergisi, 6(2), 119-148.

Donovan, J. (2014). Feminist Teori. İstanbul: İletişim Yayınları.

Eroğlu, A. Y., \& Arslan, B. (2017). Yerel Basında Kadın Gazeteciler (Mersin Yerel Basın Örneği). E. Doğan, \& E. Geçgin içinde, Current Debates In Public Relations Cultural \& Media Studies (s. 267-285). London: IJOPEC Publication.

Gezgin, S. (2007). Türkiye'de Yerel Basın. S. Gezgin içinde, Türkiye'de Yerel Basın (s. 177-196). İstanbul: İstanbul Üniversitesi İletişim Fakültesi Yayınları.

Holvino, E. (2010). Intersections: The Simultaneity of Race, Gender and Class in Organization Studies. Gender, Work and Organization, 17(3), 249-277.

Kara, N. Ç. (2019, 09 12). Toplumsal cinsiyet eşitliği nedir, Türkiye'de neden tartışma yaratıyor? 012020 tarihinde BBC: https://www.bbc.com/turkce/haberler-turkiye-49679143 adresinden alındı

Nalcıoğlu, B. U. (2007). Yerel Kamuoyunun Kitle İletişim Aracı Olarak Yerel Basın. S. Gezgin içinde, Türkiye'de Yerel Basın (s. 197-211). İstanbul: İstanbul Üniversitesi İletişim Fakültesi Yayınları.

Özdemir, Ö. (2017). İki Sistemli Kuram Olarak Sosyalist Feminizm. Karadeniz Sosyal Bilimler Dergisi, 9(2), 395-414.

Şeker, M. (2007). Yerel Gazeteler. Konya: Tablet Kitabevi.

Tekvar, S. O. (2016). Kadın Gazeteci Olmak: Uçan Haber "Kadın ve Medya” Özel Sayısının İncelenmesi. Karabük Üniversitesi Sosyal Bilimler Enstitüsü Dergisi, 6(2), 435-445.

TGS (Türkiye Gazeteciler Sendikası). (2018, Mart). Gazeteci Kadınların Yaşadığ Cinsiyet Ayrımcılı̆̆ı ve Şiddet Araştırması Raporu. Mayıs 18, 2020 tarihinde e.issuu.com: https://e.issuu.com/anonymous-embed.html?u=tgs1952\&d=tgs-kadin-rapor adresinden alındı 
Nedim Serhat BíLECEN

Yerel Basında Kadın Çalışanların Konumu ve Sorunları: Giresun Yerel Basın Örneği

TÜİK. (2019). Yazılı Medya İstatistikleri, 2018. Nisan 30, 2020 tarihinde Türkiye İstatistik Kurumu:

http://tuik.gov.tr/PreHaberBultenleri.do;jsessionid=139fptCbgmTtv6npMW0wyCsnPVn yQZKLs0GmgPnKGg8351JVX5n2!1614207981?id=30593 adresinden alındı 